\title{
PEMANFAATAN KOMPOS PADA LAHAN KRITIS UNTUK MENUNJANG PRODUKSI BAWANG MERAH, KACANG TANAH, DAN KEDELE DI KABUPATEN MINAHASA UTARA
}

\author{
UTILIZATION OF COMPOST IN THE CRITICAL LAND TO SUPPORT THE PRODUCTION \\ OF ONIONS, PEANUTS, AND SOYABEANS IN NORTH MINAHASA MUNICIPLE
}

\author{
Joice M.J. Supit, Yani E.B. Kamagi dan Wiesje J. Kumolontang*) \\ *)Dosen Fakultas Pertanian Unsrat Manado, 95115
}

\begin{abstract}
The experiment pot of the effect compost in the critical land on the production onions, peanuts, and soybeans, the goal is to get organic agricultural production and determine the optimal dose of compost for plant onions, peanuts and soybeans. Before the experiment of compost treatment was conducted the compost and soil as media plant to analyse the chemical properties. After the experiment of compost treatment was conducted the soil as media plant to analyse the chemical properties. The experiment design of methode was used complate randamized design (CRD) with the five treatment compost and four replication. Dosage of compost consists of 0 tonnes $/ \mathrm{ha}(0 \mathrm{~g} / \mathrm{pot})$ as a control, 30 tonnes /ha $(75 \mathrm{~g} / \mathrm{pot}) ; 60$ tonnes/ha (150 g/pot); 90 tonnes/ha $(225 \mathrm{~g} / \mathrm{pot})$, and 120 tonnes/ha (300 $\mathrm{g} / \mathrm{pot})$. The parameter were observed wet weight of plants, quantity and weight beet the production plant of onions; wet weight of plants, quantity and weight of pod pea and seed the production plant of peanuts and soyabeans. The data of analysis was used the analysis of variance (Anova) and the least significant difference (LSD). The results showed that treatment of compost very significant effect on the growth and production of plant onions, peanuts and soybeans. Treatment compost 90 tonnes/ha (225 g/pot) provide growth and yield of plant onion, peanuts, and soybeans maximum. Keywords: compost, onion, peanut, soybean, critical land
\end{abstract}

\begin{abstract}
ABSTRAK
Percobaan pot pengaruh kompos pada lahan kritis terhadap produksi bawang merah, kacang tanah, dan kedelai dengan tujuan untuk mendapatkan produksi pertanian organik dan menentukan dosis kompos yang optimum untuk tanaman bawang merah, kacang tanah, dan kedelai. Sebelum percobaan perlakuan kompos dilakukan analisis beberapa sifat kimia dari kompos dan tanah sebagai media tanam. Sesudah percobaan perlakuan kompos dilakukan analisis beberapa sifat kimia dari tanah sebagai media tanam. Metode rancangan percobaan yang digunakan adalah rancangan acak lengkap (RAL) dengan 5 (lima) perlakuan kompos dan 4 (empat) ulangan. Perlakuan dosis kompos terdiri dari 0 ton/ha $(0 \mathrm{~g} / \mathrm{pot})$ sebagai kontrol, 30 ton /ha $(75 \mathrm{~g} / \mathrm{pot}) ; 60$ ton/ha (150 g/pot); 90 ton/ha (225 g/pot), dan 120 ton/ha (300 g/pot). Parameter yang diamati adalah berat basa tanaman, jumlah umbi, berat umbi untuk tanaman bawang merah; berat basa tanaman, jumlah polong, berat polong, jumlah biji, dan berat biji untuk tanaman kacang tanah dan kedelai. Data hasil pengamatan dianalisis dengan analisis varians dan analisis beda nyata terkecil ( BNT). Hasil percobaan ini menunjukkan bahwa perlakuan kompos berpengaruh sangat nyata terhadap pertumbuhan dan produksi tanaman bawang merah, kacang tanah, dan kedelai. Perlakuan kompos dengan dosis 90 ton/ha (225 g/pot) memberikan pertumbuhan dan produksi tanaman bawang merah, kacang tanah, dan kedelai yang maksimum.

Kata kunci : kompos, bawang merah, kacang tanah, kedelai, lahan kritis
\end{abstract}




\section{PENDAHULUAN}

Indikator lahan kritis adalah tumbuhnya vegetasi alang-alang di lahan tersebut. Lahan kritis terjadi karena pengelolaan lahan tidak dilakukan prinsip konservasi tanah terhadap lahan-lahan dengan kemiringan lereng di atas 15\% sehingga pada musim hujan terjadi erosi tanah. Fungsi produksi berkaitan dengan fungsi tanah sebagai sumber unsur hara bagi tumbuhan dan fungsi tata air berkaitan dengan fungsi tanah sebagai tempat berjangkarnya akar dan menyimpan air tanah. Perbaikan lahan kritis melalui tindakan konservasi telah banyak dilakukan di Indonesia antara lain : pembuatan teras, pengolahan tanah menurut kontur, penanaman tanaman pohon, pergiliran tanaman, penambahan pupuk organik, anorganik dan kapur, pengembalian sisa tanaman/jerami, pembuatan lobang penahan/penampung air hujan (Anonimous, 2011).

Kemajuan Iptek yang di hasilkan sejak tahun 1970an di bidang pertanian khususnya dalam peningkatan produksi baik tanaman semusim maupun tanaman tahunan. Adapun teknologi pertanian tersebut adalah pupuk dan pestisida serta teknik konservasi tanah yang bertujuan untuk meningkatkan dan mempertahankan produksi pertanian. Tetapi dengan adanya pengkajian yang lebih mendalam terhadap teknologi pertanian khususnya pupuk dan pestisida telah menunjukkan teknologi tersebut tidak ramah lingkungan. Teknologi pertanian ini tidak ramah lingkungan karena terjadinya pengendapan unsur logam-logam berat dalam produksi pertanian dan berfungsi racun bagi tubuh manusia.

Kompos adalah bahan organik yang berasal dari sisa-sisa tanaman yang telah menjadi lapuk, seperti daun-daunan, jerami, alang-alang, rumput-rumputan, serta kotoran hewan. Bahan organik terjadi dari bahan-bahan yang berasal dari organisme hidup yang dapat mengalami proses dekomposisi dari bahan-bahan yang tersusun atas senyawa-senyawa organik (Soemarno, 2007). Jenis-jenis bahan ini akan menjadi lapuk dan busuk bila berada dalam keadaan basah dan lembab dan akan berubah menjadi bagian dari tanah. Di lingkungan alam terbuka kompos bisa terjadi dengan sendirinya lewat proses alami, karena kerja sama antara mikro organis dengan cuaca. Tetapi proses tersebut bisa dipercepat oleh perlakuan manusia, hingga menghasilkan kompos yang berkualitas baik dan dapat berperan besar terhadap perbaikan sifatsifat tanah dengan maksud agar mendatangkan hasil yang maksimal. Kompos merupakan pupuk organik dari hasil pelapukan bahan-bahan tanaman atau limbah tanaman, yang terjadi karena perlakuan manusia. Perlakuan dalam pengomposan dapat dipercepat dengan cara penambahan mikroorganisme dekomposer atau activator (Indriyani, 2002). Nyakpa, dkk. (1988) mengemukakan pupuk organik yang berasal dari sisa-sisa organik berupa tanaman, kotoran padat dan cair hewan ternak, serta kotoran burung laut dan kelelawar yang telah mengalami proses pelapukan. Pada umumnya pupuk organik mengandung unsur hara lebih lengkap yaitu unsur hara makro dan mikro meskipun dalam jumlah yang sedikit. Pemberian pupuk organik ke dalam tanah membawa dampak positif bagi tanah dan tanaman. Peranan bahan organik di dalam tanah adalah memperbaiki sifat fisik, kimia dan biologi tanah. Pengaruh bahan organik yang telah menjadi kompos terhadap sifat fisik tanah di antaranya merangsang granulasi, memperbaiki aerasi tanah, dan meningkatkan kemampuan menahan air.

Bawang merah (Allium cepa, L) tumbuh baik di daerah beriklim kering dan membutuhkan penyinaran cahaya matahari minimal $70 \%$ penyinaran, suhu udara $25-32^{\circ} \mathrm{C}$ dan kelembaban nisbi $50-70 \%$, ketinggian tempat yang optimal untuk pertumbuhan dan perkembangan antara 0 $450 \mathrm{mdpl}$, jenis tanah yang paling cocok adalah tanah aluvial atau kombinasi dengan tanah latosol, berstruktur remah, dan tekstur sedang sampai kuat, drainase/aerasi baik, reaksi tanah tidak masam $(\mathrm{pH}$ tanah 5,6-6,5), mengandung bahan organik yang cukup (Sutarya dan Grubben, 1995; Nasarudin, 1999). Tanaman bawang merah dapat membentuk umbi di daerah yang suhu rata-rata $22^{\circ} \mathrm{C}$, di bawah suhu ini tanaman bawang merah tidak akan berumbi. Oleh karena itu tanaman ini lebih menyukai tumbuh di dataran rendah dengan iklim sedang (Rismunandar, 1986). Kacang Tanah (Arachys hypogeal, L) dapat tumbuh dengan curah hujan 
antara 800-1300 mm/tahun, suhu udara sekitar 28$32^{\circ} \mathrm{C}$, kelembaban udara berkisar $65-75 \%$, penyinaran matahari penuh, terutama kesuburan daun dan perkembangan besarnya kacang tanah, $\mathrm{pH}$ tanah antara 6,0-6,5. Keadaan tanah yang sesuai adalah tanah gembur/berstruktur ringan dan subur, drainase dan aerasi baik, ketinggian tempat di bawah $1.500 \mathrm{~m}$ dpl.

Kedelai (Glycine maxi L.) sebagian besar tumbuh di daerah yang beriklim tropis dan subtropics. Iklim kering disukai tanaman kedelai dibandingkan iklim lembab (Sumarno, 1987). Menurut Suprapto (1997) tanaman kedelai dapat tumbuh baik di daerah yang memiliki curah hujan sekitar $100-400 \mathrm{~mm} / \mathrm{bulan}$. Produksi optimal bagi tanama kedelai membutuhkan curah hujan antara 100-200 $\mathrm{mm} / \mathrm{bulan}$. Suhu yang dikehendaki tanaman kedelai antara $21-34^{\circ} \mathrm{C}$, akan tetapi suhu optimum bagi pertumbuhan tanaman kedelai $23-27^{\circ} \mathrm{C}$. Toleransi keasaman tanah sebagai syarat tumbuh bagi kedelai adalah $\mathrm{pH}=5,8-7,0$ (Irwan, 2006). Pada $\mathrm{pH}$ kurang dari 5,5 pertumbuhan sangat terlambat karena keracunan aluminium. Pertumbuhan bakteri bintil dan proses nutrifikasi (proses oksidasi amoniak menjadi nitrit atau proses pembusukan) akan berjalan kurang baik (Sumarno, 1987).

Untuk melihat peran kompos sebagai pupuk organik akan menghasilkan produksi pertanian organik, maka dilakukan kajian pemanfaatan kompos pada lahan kritis untuk menunjang produksi bawang merah, kacang tanah, dan kedelai di kabupaten Minahasa Utara.

\section{METODE PENELITIAN}

Penelitian ini dilaksanakan di rumah kaca Fakultas Pertanian Unsrat dan analisis tanah dilakukan di laboratorium Kimia dan Kesuburan Tanah Fakultas Pertanian Unsrat Manado. Media tanah berasal dari lahan kritis Desa Tiwoho Kecamatan Wori Kabupaten Minahasa Utara dengan waktu penelitian mulai Bulan April - Oktober 2015. Bahan yang digunakan dalam penelitian ini adalah : bibit bawang merah, benih kacang tanah, dan benih kedelai serta kompos. Alat yang digunakan dalam penelitian ini antara lain: ember, meteran, timbang- an, alat tulis-menulis, karung, ayakan, dan sekop. Variabel yang diamati adalah produksi yang meliputi berat segar tanaman, jumlah umbi/biji, berat umbi/biji tanaman bawang merah; Berat segar tanaman,jumlah polong/biji, berat polong/biji tanaman kacang tanah dan kedelai. Metode percobaan yang digunakan adalah Rancangan Acak Lengkap (RAL) dengan 5 perlakuan dosis kompos dan 4 ulangan. Dosis kompos adalah $\mathrm{Po}=0$ ton/ha $(0 \mathrm{gr} / \mathrm{pot}) \mathrm{se}-$ bagai kontrol, $\mathrm{P} 1=30$ ton/ha $(75 \mathrm{gr} / \mathrm{pot}), \mathrm{P} 2=60$ ton/ha (150 gr/pot), P3= 90 ton/ha (225 gr/pot), dan P4= 120 ton/ha $(300 \mathrm{gr} / \mathrm{pot}) ;$ Tiap ember/pot berisi media tanah $10 \mathrm{~kg}$; Media tanah diambil dari lahan kritis pada lapisan olah dengan kedalaman $20 \mathrm{~cm}$ dari permukaan. Prosedur penelitian meliputi tahap: 1) pencampuran tanah dengan kompos sesuai dosis kemudian dimasukan kedalam ember/pot; 2) inkubasi dilakukan melalui penyiraman terhadap tanah dan kompos dalam pot selama dua minggu; 3) Setelah itu bibit tanaman ditanam di pot; 4) setelah 10 hari dilakukan penjarangan dimana setiap ember dibiarkan 2 tanaman; 5) pemeliharaan tanaman sampai umur produktif. Data ditabulasi dan dianalisis dengan Analisa Sidik Ragam (Anova) dan uji beda nyata terkecil (BNT) $5 \%$ (Steel and Torries, 1976). Analisis laboratorium dilakukan terhadap beberapa sifat kimia tanah dan kompos. Adapun sifat kimia yang dianalisis adalah $\mathrm{pH} \mathrm{H}_{2} \mathrm{O}$ dengan metode $\mathrm{pH}$ meter, $\mathrm{C}$-organik dengan metode Walkey dan Black (Black, 1965), N total dengan metode Kjeldahl (Black, 1965), P tersedia dan K tersedia dengan metode Black (Black, 1965).

\section{HASIL DAN PEMBAHASAN}

Berdasarkan hasil analisis sifat kimia terhadap pupuk kompos menunjukkan bahwa kandungan unsur hara seperti $\mathrm{N}$-total tergolong tinggi, $\mathrm{P}$ tersedia tergolong sedang, $\mathrm{K}$ tersedia tergolong sangat tinggi, $\mathrm{C}$ - organik tergolong sangat tinggi, dan $\mathrm{pH} \mathrm{H}_{2} \mathrm{O}$ tergolong agak masam (Tabel 1). Berdasarkan kandungan unsur hara dari pupuk kompos dapat mempengaruhi peningkatan unsur hara yang terkandung pada tanah sebelum perlakuan pupuk kompos. 
Tabel 1. Analisis Beberapa Sifat Kimia Kompos dan Tanah Sebelum Perlakuan Kompos

(Table 1. The Analysis of Some Chemical Properties of Compost and Soil Before Compost Treatment)

\begin{tabular}{lcccc}
\hline \multirow{2}{*}{ Sifat Kimia Kompos } & \multicolumn{2}{c}{ Pupuk Kompos } & \multicolumn{2}{c}{ Tanah Sebelum Perlakuan } \\
\cline { 2 - 5 } & Hasil Analisis & Kategori & Hasil Analisis & Kategori \\
\hline $\mathrm{pH} \mathrm{H} \mathrm{H}_{2} \mathrm{O}$ & 6,37 & agak masam & 6,32 & agak masam \\
$\mathrm{C}$ - Organik (\%) & 15,11 & sangat tinggi & 1,82 & rendah \\
$\mathrm{N}$ total $(\%)$ & 1,11 & tinggi & 0,16 & rendah \\
$\mathrm{P}$ tersedia $(\mathrm{ppm})$ & 22,34 & sedang & 10,50 & sedang \\
$\mathrm{K}$ tersedia $(\mathrm{mg} / 100 \mathrm{~g})$ & 20,23 & sangat tinggi & 1,69 & sangat rendah \\
\hline
\end{tabular}

Sumber : Data Hasil Analisis di Laboratorium Kimia dan Kesuburan Tanah Fak. Pertanian Unsrat Manado

Tabel 2. Rerata Analisis Beberapa Sifat Kimia Terhadap Tanah Sesudah Perlakuan Kompos

(Table 2. Average of the Some Chemical Properties on Soil After Compost Treatment)

\begin{tabular}{llccccc}
\hline \multirow{2}{*}{ No Sifat Kimia } & \multicolumn{5}{c}{ Perlakuan } \\
\cline { 3 - 6 } & & $\mathrm{P} 0$ & $\mathrm{P} 1$ & $\mathrm{P} 2$ & $\mathrm{P} 3$ & $\mathrm{P} 4$ \\
\hline 1. & $\mathrm{pH} \mathrm{H} \mathrm{H}_{2} \mathrm{O}$ & 6,33 & 6,34 & 6,34 & 6,35 & 6,37 \\
& Kategori & Agak & Agak & Agak & Agak & Agak \\
& & masam & Masam & Masam & Masam & Masam \\
2. & C-Orgaik(\%) & 1,83 & 2,14 & 3,05 & 3,15 & 3,36 \\
& Kategori & Rendah & Sedang & Tinggi & Tinggi & Tinggi \\
3. & N-Total (\%) & 0,17 & 0,20 & 0,24 & 0,29 & 0,31 \\
& Kategori & Rendah & Rendah & Sedang & Sedang & Sedang \\
4. & P tersedia(ppm) & 10,52 & 11,37 & 12,56 & 13,06 & 15,46 \\
& Kategori & Rendah & Rendah & Rendah & Sedang & Sedang \\
5. & K Tersedia(mg/100 gr) & 1,70 & 2,09 & 2,86 & 3,86 & 4,99 \\
& Kategori & Sangat & Sangat & Sangat & Sangat & Sangat \\
& & Rendah & Rendah & Rendah & rendah & rendah \\
\hline
\end{tabular}

Sumber : Data Hasil Analisis di Laboratorium Kimia dan Kesuburan Tanah Fak. Pertanian Unsrat Manado

Hasil analisis sifat kimia terhadap tanah sebelum perlakuan pupuk kompos menunjukkan bahwa tanah di lokasi penelitian mempunyai kandungan unsur hara seperti $\mathrm{N}$ total tergolong rendah, $\mathrm{P}$ tersedia tergolong rendah dan $\mathrm{K}$ tersedia tergolong sangat rendah, sedangkan $\mathrm{pH}_{2} \mathrm{O}$ tergolong agak masam dan kandungan bahan organik tergolong rendah. Tanah-tanah seperti ini akan menghasilkan produksi yang rendah apabila ditanami tanpa dibarengi dengan pemupukan atau penambahan hara.

Hasil analisis sifat kimia terhadap tanah sesudah perlakuan pupuk kompos menunjukkan bahwa terjadi peningkatan kandungan unsur hara di tanah atau perubahan kuantitatif kandungan unsur hara seiring dengan peningkatan dosis pupuk kompos (Tabel 2). Peningkatan kandungan unsur hara pada perlakuan pupuk kompos maka hal ini akan mempengaruhi peningkatan produksi tanaman.

\section{Tanaman Bawang Merah}

Pengaruh pemberian pupuk kompos terhadap berat segar tanaman, jumlah umbi, dan berat umbi tanaman bawang merah dapat disajikan pada Tabel 3. Hasil analisis sidik ragam menunjukkan adanya pengaruh yang sangat nyata perlakuan kompos terhadap berat segar, jumlah umbi dan berat umbi tanaman bawang merah. 
Tabel 3. Rerata Berat Segar, Jumlah dan Berat Umbi Tanaman Bawang Merah

(Table 3. Average The Wet Weight of Plant, Quantity and Weight Beet The Plant of Onion)

\begin{tabular}{ccccc}
\hline \multirow{2}{*}{ No } & \multirow{2}{*}{ Perlakuan } & \multicolumn{3}{c}{ Variabel Yang Diamati } \\
\cline { 3 - 5 } & BmPo & Berat Segar Tanaman & Jumlah Umbi & Berat Umbi \\
\hline 1. & $24,34 \mathrm{a}$ & $16,50 \mathrm{a}$ & $20,53 \mathrm{a}$ \\
2. & BmP1 & $47,86 \mathrm{~b}$ & $25,00 \mathrm{~b}$ & $39,68 \mathrm{~b}$ \\
3. & BmP2 & $71,52 \mathrm{c}$ & $37,25 \mathrm{c}$ & $57,39 \mathrm{c}$ \\
4. & BmP3 & $122,98 \mathrm{e}$ & $62,75 \mathrm{e}$ & $113,69 \mathrm{e}$ \\
5. & BmP4 & $98,82 \mathrm{~d}$ & $54,25 \mathrm{~d}$ & $68,94 \mathrm{~d}$ \\
\hline \multicolumn{2}{c}{ BNT(.05;15) } & 7,123 & 3,098 & 5,652 \\
\hline
\end{tabular}

Sumber : Data Hasil Pengamatan

Keterangan: Angka yang diikuti oleh huruf yang berbeda pada kolom yang sama berbeda nyata menurut BNT pada taraf $5 \%$

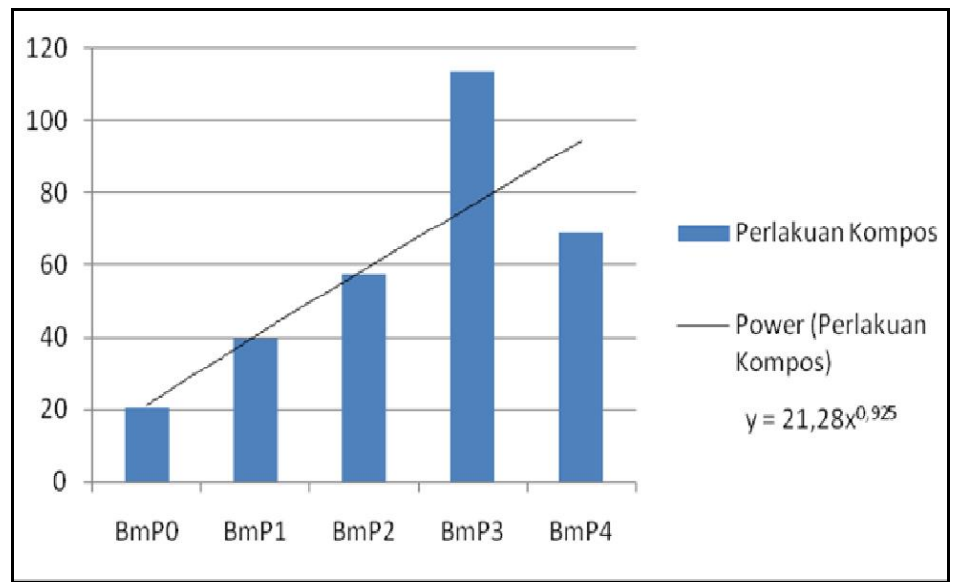

Gambar 1. Pengaruh Perlakuan Kompos Terhadap Produksi Bawang Merah

(Figure 1. Effect of Compost on The Production of Plant Onions)

Tabel 3 memperlihatkan bahwa perlakuan kompos memberikan perbedaan yang nyata antar perlakuan terhadap berat segar, jumlah umbi, dan berat umbi tanaman bawang merah. Perlakuan tanpa pemberian pupuk kompos (BmPo) menunjukkan nilai terendah pada setiap variabel yang diamati. Hal ini menunjukkan bahwa tanah yang digunakan sangat membutuhkan tambahan hara karena ketersediaannya rendah untuk menunjang proses pertumbuhan dan produksi tanaman bawang merah. Perlakuan dengan pemberian kompos menunjukkan hasil yang lebih tinggi dan tertinggi berada pada perlakuan BmP3 dengan dosis kompos 90 ton/ha atau $225 \mathrm{gr} /$ pot. Hal ini memberikan petunjuk bahwa kompos yang diberikan sangat membantu dan memberikan sumbangan hara yang sangat dibutuhkan tanaman.

Gambar 1 menunjukkan bahwa perlakuan BmP3 memberikan produksi tertinggi umbi bawang merah. Dari persamaan nilai duga yaitu: $y=$ $21,28 \mathrm{x}^{0,925}$, di mana setiap penambahan satu satuan dosis pupuk kompos akan memberikan tambahan hasil sebesar $21,28 \mathrm{gr}$ umbi bawang merah per pot. Dari Gambar 1, menunjukkan bahwa peningkatan dosis seperti pada perlakuan BmP4 tidak akan memberikan tambahan produksi bawang merah. Sehingga dapat disimpulkan bahwa penambahan dosis pupuk kompos setelah perlakukan BmP3 tidak akan memberikan hasil yang meningkat.

Pertumbuhan dan perkembangan yang baik akan memberikan hasil yang baik pula. Untuk mendapatkan pertumbuhan tanaman yang baik dan memberikan hasil tinggi, dibutuhkan unsur-unsur hara yang tersedia dan dapat dimanfaatkan oleh tanaman harus dalam keadaan cukup. Menurut Nyakpa, dkk. (1988) unsur-unsur N, P, dan K dikenal sebagai unsur hara utama, sedangkan $\mathrm{Ca}$, 
$\mathrm{Mg}$, dan S sebagai unsur hara sekunder, dan sisanya sebagai unsur hara mikro.

\section{Tanaman Kacang Tanah}

Pengaruh perlakuan pupuk kompos terhadap berat segar, jumlah polong, berat polong, jumlah biji, dan berat biji kacang tanah dapat disajikan pada Tabel 4. Hasil analisis sidik ragam menunjukkan adanya pengaruh sangat nyata perlakuan pupuk kompos terhadap berat segar, jumlah polong, berat polong, jumlah biji, dan berat biji tanaman kacang tanah.

Tabel 4 menunjukkan perlakuan kompos memberikan perbedaan yang sangat nyata antar perlakuan terhadap berat segar, jumlah polong, berat polong, jumlah biji, dan berat biji tanaman kacang tanah. Perlakuan tanpa pemberian kompos (KtPo) memberikan nilai terrendah dan berbeda sangat nyata dengan perlakuan pemberian kompos. Perlakuan pemberian kompos pada perlakuan KtP3 (90 ton/ha atau $225 \mathrm{gr} / \mathrm{pot}$ ) memberikan nilai tertinggi pada setiap variable yang diamati. Perlakuan ini memberikan petunjuk bahwa hara yang dibutuhkan tanaman dalam proses pertumbuhan dan produksi sudah cukup tersedia dan dapat diserap tanaman.

Sutanto (2002) mengemukakan bahwa penggunaan pupuk organik yang tepat waktu dan cukup akan meningkatkan hasil tanaman. Pupuk organik dalam hal ini kompos berperan pada sifat fisik, kimia dan biologi tanah (Stevenson, 1994). Peranan pupuk organik terhadap fisik tanah adalah memperbaiki struktur tanah. Perbaikan sifat kimia tanah, pupuk organik menyumbang hara ke tanah dan meningkatkan kapasitas tukar kation (KTK) tanah. Sedangkan perbaikan sifat biologi tanah, pupuk organik yang berasal dari berbagai sumber bahan organik dapat membawa jasad renik yang bermanfaat bagi perbaikan sifat fisik dan kimia tanah, sehingga pada akhirnya akan berpengaruh positif pada pertumbuhan dan produksi tanaman (Tisdale dan Nelson, 1975).

Kompos mengandung unsur hara makro dan mikro. Nitogen merupakan sumber unsur hara makro dan bahan penting penyusun asam amino, amida, nukleotida dan nucleoprotein, serta esensial untuk pembelahan sel dan pembesaran sel. Sebab itu nitrogen sangat berperan pada pertumbuhan tanaman. $\mathrm{P}$ diantaranya merupakan komponen penting penyusun senyawa untuk transfer energi ATP dan nucleoprotein lain. $\mathrm{K}$ membantu memelihara potensial osmotik dan pengambilan air dan berperan penting dalam fotosintesis karena secara langsung meningkatkan pertumbuhan dan indeks luas daun, karenanya juga meningkatkan $\mathrm{CO} 2$ serta meningkatkan translokasi hasil fotosintesis (Gardner, dkk., 1991).

Kekurangan unsur $P$ akan mengakibatkan banyak polong kacang tanah yang tidak berisi dan mengurangi jumlah bunga serta jumlah ginofor akibatnya hasil kacang tanah akan rendah. Kalium dibutuhkan untuk meningkatkan kadar lemak dalam biji, disamping peningkatan daya tahan terhadap kekeringan maupun penyakit. Selain peran unsur hara makro pada pertumbuhan dan produksi kacang tanah yang diberikan pupuk NPK organik, juga unsur hara mikro juga berperan dalam reaksi enzimatik. Tersedianya Ca dalam tanah akan mendorong perkembangan polong dan akibatnya produksi kacang tanah akan meningkat.

Pemanfaatan kompos pada tanaman akan memperbaiki sifat fisik, kimia, dan biologi tanah. Polong tanaman kacang tanah tumbuh dan berkembang di dalam tanah yang struktur tanahnya baik (berstruktur sedang sampai kasar) dan mengandung bahan organik baik untuk pertumbuhan dan perkembangan polong kacang tanah. Polong kacang tanah yang banyak dan berat mempengaruhi jumlah biji dan berat biji kacang tanah.

Gambar 2 menunjukkan bahwa perlakuan KtP3 memberikan produksi tertinggi kacang tanah. Persamaan nilai duga yaitu: $y=35,05 x^{0,465}$, di mana setiap penambahan satu satuan dosis pupuk kompos akan memberikan tambahan produksi sebesar 35,05 gram kacang tanah per pot.

Gambar 2 menunjukkan bahwa peningkatan dosis seperti pada perlakuan KtP4 tidak akan memberikan tambahan produksi kacang tanah. Sehingga dapat disimpulkan bahwa penambahan dosis pupuk kompos setelah perlakukan KtP3 tidak akan memberikan produksi yang meningkat. 
Tabel 4. Rerata Berat Segar, Jumlah Polong, Berat Polong, Jumlah Biji, dan Berat Biji Tanaman Kacang Tanah (Table 4. Average of The Wet Weight Plant, Quantity, Weigth Pod Pea and Seed The Plant of Peanut)

\begin{tabular}{lllllll}
\hline \multirow{2}{*}{ No } & \multirow{2}{*}{ Perlakuan } & \multicolumn{5}{c}{ Variabel Yang Diamati } \\
\cline { 3 - 7 } & & Berat Segar & Jmlh Polong & Berat Polong & Jmlh Biji & Berat Biji \\
\hline 1. & KtP0 & $171,60 \mathrm{a}$ & $27,00 \mathrm{a}$ & $43,58 \mathrm{a}$ & $54,00 \mathrm{a}$ & $37,20 \mathrm{a}$ \\
2. & KtP1 & $204,13 \mathrm{~b}$ & $33,25 \mathrm{~b}$ & $54,98 \mathrm{~b}$ & $66,50 \mathrm{~b}$ & $43,69 \mathrm{~b}$ \\
3. & KtP2 & $213,48 \mathrm{bc}$ & $55,00 \mathrm{c}$ & $71,16 \mathrm{c}$ & $110,00 \mathrm{c}$ & $54,47 \mathrm{c}$ \\
4. & KtP3 & $234,18 \mathrm{c}$ & $73,50 \mathrm{e}$ & $97,92 \mathrm{e}$ & $145,75 \mathrm{e}$ & $78,00 \mathrm{e}$ \\
5. & KtP4 & $229,05 \mathrm{c}$ & $64,50 \mathrm{~d}$ & $88,07 \mathrm{~d}$ & $129,00 \mathrm{~d}$ & $71,23 \mathrm{~d}$ \\
\hline \multicolumn{2}{l}{ BNT(15;:05) } & 24,086 & 2,478 & 3,035 & 5,206 & 1,319 \\
& $(15 ; .01)$ & 33,309 & 3,427 & 4,197 & 7,199 & 1,824 \\
\hline
\end{tabular}

Sumber : Data Hasil Pengamatan

Keterangan: Angka yang diikuti oleh huruf yang berbeda pada kolom yang sama berbeda nyata menurut BNT pada taraf $5 \%$.

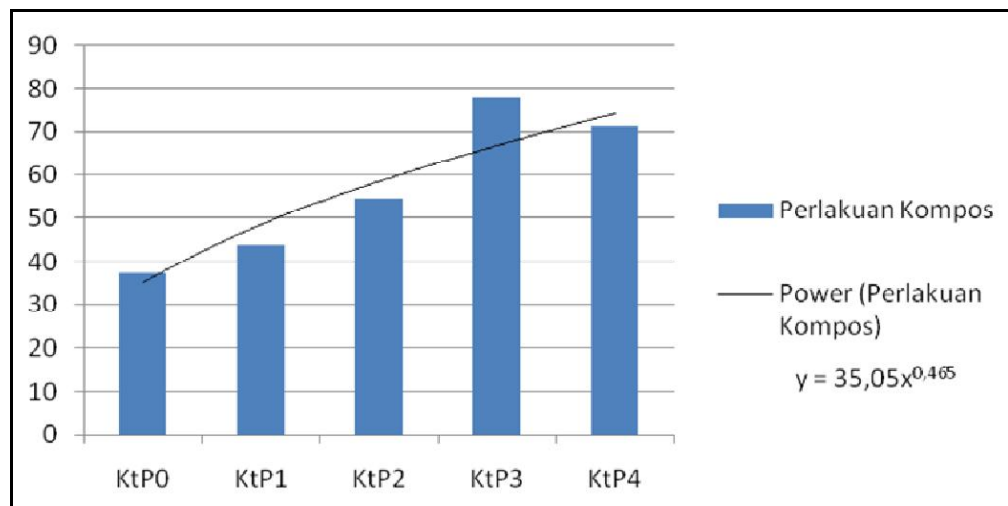

Gambar 2. Pengaruh Perlakuan Kompos Terhadap Produksi Kacang Tanah

(Figure 2. Effect of Compost Treatment on the Production of Plant Peanuts)

\section{Tanaman Kedelai}

Pengaruh perlakuan pupuk kompos terhadap berat segar, jumlah polong, berat polong, jumlah biji, dan berat biji tanaman kedelai disajikan dalam Tabel 5. Hasil analisis sidik ragam menunjukkan adanya pengaruh sangat nyata perlakuan pupuk kompos terhadap berat segar, jumlah polong, berat polong, jumlah biji, dan berat biji tanaman kedelai.

Tabel 5 dapat dilihat perlakuan kompos memberikan perbedaan yang sangat nyata terhadap berat segar, jumlah polong, berat polong, jumlah biji, dan berat biji tanaman kedelai. Perlakuan tanpa pemberian pupuk kompos (KPo) memberi nilai terendah dan berbeda nyata dengan perlakuan pemberian kompos. Hasil penelitian menunjukkan pemberian kompos pada perlakuan KP3 (90 ton/ha atau $225 \mathrm{gr} / \mathrm{pot}$ ) memberikan nilai tertinggi dan berbeda nyata dengan perlakuan lainnya. Hal ini menunjukkan pemberian kompos pada perlakuan yang demikian dapat menyediakan hara yang cukup untuk menunjang pertumbuhan dan produksi tanaman kedelai.

Tanaman yang tidak diberi kompos menunjukkan nilai yang lebih rendah dibandingkan dengan tanaman yang diberi kompos. Hal ini menunjukkan bahwa tanaman sangat membutuhkan unsur hara yang lebih dari yang ada di dalam tanah. Tidak adanya penambahan unsur hara menyebabkan proses pembelahan sel dalam tanaman terganggu akibanya pertumbuhan tanaman terhambat. Pemberian pupuk organik seperti kompos akan mentransformasikan unsur $\mathrm{N}, \mathrm{P}$, dan $\mathrm{S}$ dalam tanah. Adanya unsur $\mathrm{P}$ yang cukup dalam tanah sangat membantu dalam proses metabolism energi (Soepardi, 1983). Pemberian $\mathrm{P}$ mempengaruhi per- 
tumbuhan akar yang akan menyerap unsur hara sehingga kebutuhan hara dalam proses pertumbuhan tanaman akan berjalan lancar.

Pemberian kompos memungkinkan tersedianya nitrogen yang dibutuhkan tanaman. Nitrogen berfungsi mempercepat pertumbuhan vegetatif tanaman dan sebagai bahan pembentukan protein (Hardjowigeno, 2003). Protein yang dibentuk digunakan untuk pembentukan protoplasma dalam sel-sel tanaman sehingga terjadi pembelahan sel. Hal ini berpengaruh pada pembentukan polong.

Unsur lain yang dibutuhkan tanaman adalah $\mathrm{P}$ dan $\mathrm{K}$. Unsur $\mathrm{P}$ berperan dalam perkembangan akar, pembentukan bunga, buah dan biji. Perkembangan akar yang baik memungkinkan penyerapan hara dari tanah dan tanaman berlangsung dengan baik, akibatnya kegiatan fisiologis berlang- sung dengan baik pula. Sedangkan unsur $\mathrm{K}$ berperan dalam mentranslokasikan zat-zat yang dibutuhkan keseluruh jaringan tanaman. Jika $\mathrm{K}$ tidak tersediamaka translokasi unsur hara tidak berlangsung dengan baik pula.

Gambar 3 menunjukkan bahwa perlakuan KP3 memberikan produksi tertinggi kedelai. Dari persamaan nilai duga yaitu: $y=28,51 x^{0,391}$, di mana setiap penambahan satu satuan dosis pupuk kompos akan memberikan tambahan hasil sebesar 28,51 gr per pot produksi kedelai. Dari Gambar 3, menunjukkan bahwa peningkatan dosis seperti pada perlakuan KP4 tidak akan memberikan tambahan produksi kedelai. Sehingga dapat disimpulkan bahwa penambahan dosis pupuk kompos setelah perlakukan KP3 tidak akan memberikan produksi yang meningkat.

Tabel 5. Rerata Berat Segar, Jumlah Polong, Berat Polong, Jumlah Biji, dan Berat Biji Tanaman Kedelai

(Table 5. Average of The Wet Weight Plant, Quantity, Weight Pod Pea and Seed The Plant of Soyabeans)

\begin{tabular}{lllllll}
\multirow{2}{*}{ No } & \multirow{2}{*}{ Perlakuan } & \multicolumn{5}{c}{ Variabel Yang Diamati } \\
\cline { 3 - 7 } & & Berat Segar & Jmlh Polong & Berat Polong & Jmlh Biji & Berat Biji \\
\hline 1. & KPo & $136,05 \mathrm{a}$ & $64,25 \mathrm{a}$ & $42,16 \mathrm{a}$ & $129,75 \mathrm{a}$ & $28,13 \mathrm{a}$ \\
2. & KP1 & $155,56 \mathrm{~b}$ & $80,00 \mathrm{~b}$ & $48,30 \mathrm{~b}$ & $163,75 \mathrm{~b}$ & $34,48 \mathrm{~b}$ \\
3. & KP2 & $198,83 \mathrm{~d}$ & $94,75 \mathrm{c}$ & $60,49 \mathrm{~d}$ & $190,75 \mathrm{c}$ & $49,22 \mathrm{~d}$ \\
4. & KP3 & $229,61 \mathrm{e}$ & $118,25 \mathrm{e}$ & $74,90 \mathrm{e}$ & $236,50 \mathrm{e}$ & $57,74 \mathrm{e}$ \\
5. & KP4 & $168,89 \mathrm{c}$ & $100,50 \mathrm{~d}$ & $55,41 \mathrm{c}$ & $201,00 \mathrm{~d}$ & $44,46 \mathrm{c}$ \\
\hline BNT(15;.05) & 5,061 & 2,540 & 3,647 & 6,099 & 1,866 \\
\hline
\end{tabular}

Sumber : Data Hasil Pengamatan

Keterangan: Angka yang diikuti oleh huruf yang berbeda pada kolom yang sama berbeda nyata menurut BNT pada taraf $5 \%$.

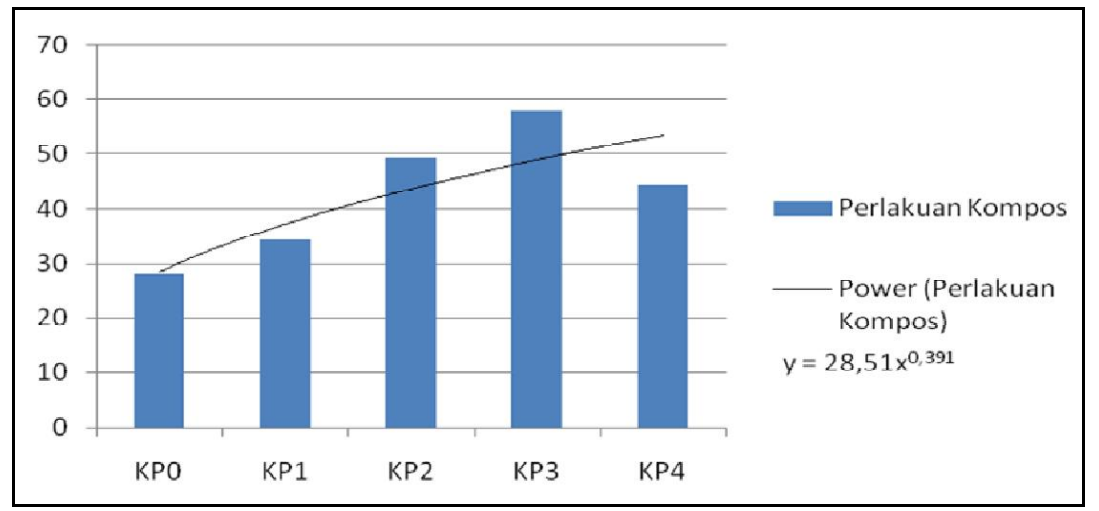

Gambar 3. Pengaruh Perlakuan Kompos Terhadap Produksi Kedelai

(Figure 3. Effect of Compost Treatment on the Production of Plant Soyabeans) 


\section{KESIMPULAN}

Hasil analisis beberapa sifat kimia terhadap tanah sebelum perlakuan pupuk kompos menunjukkan kandungan unsur hara tergolong sangat rendah sampai rendah. Kesuburan tanah seperti ini akan menghasilkan produksi yang rendah apabila ditanami tanpa dibarengi dengan pemupukan atau penambahan hara melalui pupuk organik atau anorganik.

Perlakuan pupuk kompos berpengaruh sangat nyata terhadap berat segar, jumlah umbi, dan berat umbi tanaman bawang merah. Perlakuan dengan pemberian pupuk kompos BmP3(90 ton/ha atau $225 \mathrm{gr} / \mathrm{pot}$ ) memberikan nilai tertinggi terhadap berat segar, jumlah umbi dan berat umbi tanaman bawang merah.

Perlakuan pupuk kompos berpengaruh sangat nyata terhadap berat segar, jumlah polong, berat polong, jumlah biji, dan berat biji tanaman kacang tanah. Perlakuan dengan pemberian pupuk kompos KP3(90 ton/ha atau $225 \mathrm{gr} /$ pot) memberikan nilai tertinggi terhadap berat segar, jumlah polong, berat polong, jumlah biji, dan berat biji tanaman kacang tanah.

Perlakuan pupuk kompos berpengaruh sangat nyata terhadap berat segar, jumlah polong, berat polong, jumlah biji, dan berat biji tanaman kedelai. Perlakuan dengan pemberian pupuk kompos KtP3(90 ton/ha atau $225 \mathrm{gr} /$ pot) memberikan nilai tertinggi terhadap berat segar, jumlah polong, berat polong, jumlah biji, dan berat $r$

\section{UCAPAN TERIMA KASIH}

Disampaikan terima kasih kepada Rektor Unsrat Manado dan Ketua Lembaga Penelitian dan Pengabdian Kepada Masyarakat Unsrat yang sudah memberi kepercayaan kepada kami untuk melaksanakan penelitian melalui skim Riset Unggulan Unsrat (RUU) dengan batuan dana PNBP Unsrat Tahun 2015.

\section{DAFTAR PUSTAKA}

Anonimous. 2011. Penanggulangan Lahan Kritis Melalui Teknologi Konsenvasi. BPTP. Sumbar,Balitbang.

Black, C.A. 1965. Methode of Soils of Analysis Part I and II American Society of Agronomist Publisher. Madison, Wisconsin. USA.

Gardner, F.P., R.B. Pearce dan R.L.Mitchell. 1991. Fisiologi Tanaman Budidaya. Penerbit Universitas Indonesia Jakarta.

Hardjowigeno. S.2003. IImu Tanah. Penerbit Akademik Pressindo. Jakarta.

Indriyani, Y.H. 2002. Membuat Kompos Secara Kilat. Penebar Swadaya. Jakarta.

Irwan, W.A. 2006. Budidaya Tanaman kedelai (Glycine max (L) Merill). Unpad.Bandung.

Nasarudin. 1999. Budidaya dan Pengaturan Panen Sayuran Dataran Rendah. Penerbit Swadaya, Jakarta.

Nyakpa, M.Y., Lubis, A.M. Pulung, M.A., Munawar Ali, Go Ban Hong, dan N. Hakim. 1988. Kesuburan Tanah. Penerbit Universitas Lampung.

Rismunandar. 1986. Membudidayakan Lima Jenis Bawang Merah. Penerbit Sinar Baru. Bandung.

Soemarno. 2007. Pengelolaan Tanah Berkelanjutan: Aplikasi bahan organik tanah. UB Malang.

Soepardi, G. 1983. Sifat dan Ciri Tanah. Jurusan IImu Tanah. Fakultas Pertanian,IPB Bogor. 
Steel, R.G.D. and J.H. Torrie. 1976. Principles and Procedures of Statistics A Biometrical Approach. McGraw-Hill.Kogakushe,LTD.

Sumarno. 1987. Kedelai dan Cara Budidaya. Yasaguna Bogor.

Suprapto. 1997. Bertanam Kedelai. Penerbit Swadaya Jakarta.

Sutarya, R. dan G. Grubben 1995. Pedoman Bertanam Sayuran Dataran Rendah. Gadjah Mada University Press. Prosea
Indonesia. Balai Penelitian Hortikultura Lembang.

Stevenson. 1994. Humus Chemistry, genesis, Compotition, Reaction. $2^{\text {nd }}$ edt. John Wiley and Sons. Canada.

Sutanto. R. 2002. Penerapan Pertanian Organik. Kanisius. Yogyakarta.

Tisdale, S. L. dan N. Nelson. 1975. Soil Fersility and Fertilizers. The Mac. Millan Companny. New York. 